\title{
Evidence for a switch in the site of relaxin production from small theca-derived cells to large luteal cells during early pregnancy in the pig
}

\author{
P. A. Denning-Kendall, S. E. F. Guldenaar and D. C. Wathes \\ Department of Anatomy, The Medical School, University of Bristol, Bristol BS8 ITD, UK
}

\begin{abstract}
Summary. The presence of immunoreactive relaxin was studied in corpora lutea of sows during the oestrous cycle and early pregnancy by immunohistochemistry and radioimmunoassay using three different anti-relaxin sera. Sections were immunostained using the peroxidase-anti-peroxidase or the immunogold-silver technique.

Before Day 14, staining in corpora lutea from non-pregnant and pregnant animals was indistinguishable. With all antisera, no immunostaining was seen on Day 3 , but was detected on Days 5-7 in cells from the theca interna. In non-pregnant animals, this immunostaining decreased and by Day 15 only an occasional large cell in the centre of the corpus luteum was stained. No staining was seen by Day 22 . The relaxin content of corpora lutea measured by radioimmunoassay remained low throughout the luteal phase. In contrast, the amount of immunoreactive relaxin in corpora lutea rose dramatically (140-fold) between Days 11 and 14 of pregnancy and by Day 14 of pregnancy immunostaining was seen in the majority of large luteal cells. By Day 20 of pregnancy the concentrations of immunoreactive relaxin had further increased.

Histochemical staining for alkaline phosphatase suggested that, while the relaxinimmunoreactive cells seen in the early luteal phase may be theca-derived, those during early pregnancy may be derived from the granulosa.

The results are compatible with the suggestion that relaxin is produced by thecaderived cells during the early luteal phase and that between Days 11 and 14 there is a switch in the site of relaxin synthesis from theca-derived cells to granulosa-derived large luteal cells. In the absence of luteolysis, as during pregnancy, this switch is accompanied by a dramatic increase in relaxin synthesis.
\end{abstract}

Keywords: relaxin; immunohistochemistry; luteal cells; pregnancy; alkaline phosphatase; pig

\section{Introduction}

Relaxin has previously been identified in corpora lutea of sows during the oestrous cycle and early pregnancy, but the data from different groups are not consistent. Sherwood \& Rutherford (1981) found a peak in relaxin concentrations, measured by bioassay and radioimmunoassay $(\sim 6 \mu \mathrm{g} / \mathrm{g})$, during the mid-luteal phase (Days 7-14), compared to much lower values during the rest of the cycle, whereas Anderson et al. (1973) found little variation, by bioassay, during the luteal phase of the oestrous cycle $(1-3 \mu \mathrm{g} / \mathrm{g}$ ), with similar levels up to Day 18 of pregnancy. Fields \& Fields (1985) demonstrated the presence of relaxin in sow corpora lutea by immunohistochemistry and found that, while only a few cells stained in the Day-14 sample from a non-pregnant pig, many cells stained by Day 17 of pregnancy. In contrast, Ali et al. (1986) reported many cells staining between Days 11 and 15 of the oestrous cycle. 
In addition, tissue culture experiments (Evans et al., 1983) and immunohistochemistry (Bagnell et al., 1987) suggest that relaxin is produced by theca cells of the preovulatory follicle, whereas in the pregnant sow staining is seen only in large luteal cells (Larkin et al., 1977), which are generally thought to be derived from the membrana granulosa (Corner, 1919).

In the present study, immunohistochemistry and radioimmunoassay were used in parallel to investigate the presence of relaxin in corpora lutea of sows during the oestrous cycle and early pregnancy. In view of the conflicting results of previous studies, we have also investigated the localization of relaxin immunoreactivity within different cell types of the corpus luteum.

\section{Materials and Methods}

\section{Animals}

Non-pregnant, sexually mature, crossbred (Landrace $\times$ Large White) sows were checked for oestrus twice daily with a vasectomized boar and the first day of oestrus was designated as Day 0 of the cycle. Pregnancy was usually achieved by insemination or mating within $12 \mathrm{~h}$ of oestrus. Two pregnant animals (Days 11 and 14) were pre-pubertal gilts which had been inseminated after treatment with 750 i.u. PMSG.

\section{Tissue preparation}

Within 20 min of death, 2 or more corpora lutea (CL) were dissected from animals on Days 3, 5, 7, 8, 9, 10,11, 12, 14 and 22 of the oestrous cycle and on Days 7, 9, 14, 20,31 and 38 of pregnancy. Each CL was cut in half; one half was placed in fixative ( $2.5 \%$ glutaraldehyde, $4.0 \%$ paraformaldehyde in $0.1 \mathrm{M}$-sodium cacodylate, $\mathrm{pH} 7.4)$ for 1 week at $4^{\circ} \mathrm{C}$. Fixed tissues were dehydrated and embedded in Paraplast (Sherwood Medical, St Louis, MO, USA). Tissue sections of $7 \mu \mathrm{m}$ were mounted on chrome alum-gelatin coated slides. The other CL halves or 2-3 different CL from the same animals and also from a pig on Day 11 of pregnancy were frozen immediately in liquid nitrogen and stored at $-80^{\circ} \mathrm{C}$ for radioimmunoassay of relaxin content.

\section{Antisera}

Anti-relaxin sera from three different sources were used. Antiserum $\mathbf{P M A B}_{4}$ was raised in our laboratory against an extract of pig relaxin prepared using Sephadex G50. When required, this antiserum was purified using a porcine CM-a relaxin affinity column. For the column, $100 \mu \mathrm{g}$ of highly purified CM-a relaxin (2000-3000 U/mg) were coupled to $150 \mathrm{mg} \mathrm{CNBr}$-activated Sepharose (Pharmacia Fine Chemicals, Uppsala, Sweden) and the resultant relaxin-Sepharose beads were mixed with $0.4 \mathrm{ml} \mathrm{PMAB}_{4}$ antiserum in $5 \mathrm{ml} 0.05 \mathrm{M}$-sodium barbitone buffer $\mathrm{pH} 8.5$, overnight at $4^{\circ} \mathrm{C}$. After removal of the supernatant, the beads were washed and antibodies bound to $\mathrm{CM}$-a relaxin were recovered by using $5 \mathrm{ml} 50 \%(\mathrm{v} / \mathrm{v})$ ethylene glycol in $0.5 \mathrm{M}$-acetic acid for $30 \mathrm{~min}$. The antibody solution was dialysed against $0.05 \mathrm{M}$-Tris, $\mathrm{pH} 7.6$, using a CX-30 ultrafiltration unit (Millipore, Bedford, MA, USA) and stored at $-20^{\circ} \mathrm{C}$.

Antiserum R6 was donated by Dr E. M. O'Byrne and Dr B. G. Steinetz. It was raised against an extract of pig relaxin purified on a Sephadex G50 column (1000 u/mg) (O'Byrne \& Steinetz, 1976).

Antiserum 1083, donated by Dr O. D. Sherwood, was prepared using heterogeneous CM-B, CM-a, and CM-a' (2500-3000 U/mg) pig relaxin as antigen (Sherwood et al., 1975).

\section{Immunohistochemistry}

Peroxidase-anti-peroxidase ( $P A P$ ) method. After dewaxing with xylene and rehydration, sections were washed for $90 \mathrm{~min}$ in $0.05 \mathrm{M}$-Tris, $\mathrm{pH} 7.6$, containing $0.9 \%(\mathrm{w} / \mathrm{v}) \mathrm{NaCl}$ and $0.5 \%(\mathrm{v} / \mathrm{v})$ Triton X-100 (Triton buffer). The sections were incubated for $20 \mathrm{~min}$ at room temperature with undiluted normal sheep serum. Excess serum was removed from the slides, without washing, and the sections were incubated with antiserum $\mathrm{PMAB}_{4}(1: 750 \mathrm{v} / \mathrm{v})$, purified $\mathrm{PMAB}_{4}$ $(1: 10 \mathrm{v} / \mathrm{v}), \mathrm{R} 6(1: 500 \mathrm{v} / \mathrm{v})$ or $1083(1: 500 \mathrm{v} / \mathrm{v})$ diluted in Triton buffer for $\mathrm{I} \mathrm{h}$ at room temperature followed by incubation for $16 \mathrm{~h}$ at $4^{\circ} \mathrm{C}$ in a moist chamber. Incubations with the second antibody (sheep anti-rabbit raised in our laboratory) at a dilution of 1:15 and rabbit PAP (UCB Bioproducts, Braine L'Alleud, Belgium) at a dilution of 1:100, were for $1 \mathrm{~h}$ each at room temperature. Peroxidase-dependent staining was developed by incubation of slides with $3,3^{\prime}$-diaminobenzidine dissolved at $0.5 \mathrm{mg} / \mathrm{ml}$ in $0.05 \mathrm{M}$-Tris, $\mathrm{pH} 7.6$, containing $0.03 \%(\mathrm{v} / \mathrm{v})$ hydrogen peroxide. Finally, the sections were rinsed in water, dehydrated in an ascending series of ethanol concentrations $(70-100 \%)$, cleared in xylene and mounted in DePeX.

Immunogold-silver staining. After dewaxing and rehydration, sections were treated with Lugol's iodine for $10 \mathrm{~min}$, rinsed in water and washed in $2.5 \%$ sodium thiosulphate until colourless. Sections were subsequently washed in 
$0.05 \mathrm{M}$-Tris, $\mathrm{pH} 8.6$, containing $0.5 \mathrm{M}-\mathrm{NaCl}$ and $0.5 \%(\mathrm{v} / \mathrm{v})$ Triton $\mathrm{X}-100$, and this buffer was used throughout the procedure. After incubation with $10 \%$ normal goat serum for $20 \mathrm{~min}$, sections were incubated with primary antisera as in the PAP method. Sections were washed in buffer and covered with $50 \%$ normal goat serum ( $20 \mathrm{~min})$. They were incubated for $90 \mathrm{~min}$ with goat anti-rabbit immunoglobulins conjugated to $5 \mathrm{~nm}$ gold particles (Auroprobe EM GAR G5, Janssen Life Sciences Products, Olen, Belgium) diluted at 1:125 in buffer supplemented with $0.8 \%$ bovine serum albumin (No. A-7638: Sigma Chemical Co. Ltd, Poole, Dorset). Sections were then washed in buffer ( $90 \mathrm{~min}$ ) and deionized water $(60 \mathrm{~min})$. Silver intensification was done using IntenSE-1 or IntenSE-2 (Janssen Life Sciences Products)

Controls. Sections of corpora lutea from Day 20 of pregnancy were included in each experiment as positive controls. Method specificity was tested by substituting normal rabbit serum $(1: 750 \mathrm{v} / \mathrm{v})$ for the rabbit anti-pig relaxin serum. Antiserum specificity was tested by absorption of each antiserum with $20 \mu \mathrm{g} \mathrm{CM}$-a relaxin $/ \mathrm{ml}$ for $16 \mathrm{~h}$ at $4^{\circ} \mathrm{C}$ before use, or by incubating antiserum with $\mathrm{CM}$-a relaxin-Sepharose beads overnight to remove relaxin-specific antibodies.

Sections from each sample were stained with haematoxylin and eosin to check for adequate fixation and to study the formation of the corpus luteum.

\section{Staining for alkaline phosphatase}

To locate the position of theca-derived cells in different samples, CL and adjacent follicles were dissected from ovaries of sows on Days 3 and 9 of the oestrous cycle and on Day 20 of pregnancy for staining of alkaline phosphatase. Tissues were processed and stained according to Gomori (1939) except that sections were incubated with substrate for $2 \mathrm{~h}$ and sodium sulphide was used for the colour reaction.

\section{Tissue extraction}

Individual CL (or piece of pre-pubertal ovary as control) were finely chopped whilst frozen and extracted using the method of Walsh \& Niall (1980). Chopped tissue was homogenized in $8 \mathrm{ml}$ of acid extraction medium containing 4000 c.p.m. ${ }^{125}$ I-labelled CM-a relaxin to assess recovery. Supernatants were applied to single octadecylsilica cartridges (Waters Associates, Milford, MA, USA), which were then washed with $20 \mathrm{ml} 10 \%$ ( $/ \mathrm{v}$ ) acetonitrile in $0.1 \%(\mathrm{v} / \mathrm{v})$ trifluoroacetic acid (TFA). Relaxin was eluted with $3 \mathrm{ml} 80 \%$ acetonitrile in $0 \cdot 1 \%$ TFA. After evaporation of acetonitrile, samples were lyophilized and recovery of ${ }^{125} \mathrm{I}$-labelled relaxin was determined.

\section{Radioimmunoassay of relaxin}

Lyophilized extracts were reconstituted in $1 \mathrm{ml} 0.05 \mathrm{M}$-sodium barbitone buffer, $\mathrm{pH} 8.5$, containing $0.5 \%$ bovine serum albumin and were measured in triplicate at 2-3 dilutions in a modified version of a previously described radioimmunoassay for pig relaxin (Taverne et al., 1982; Evans et al., 1983). NIH-RXN-PI was used as the standard and $\mathrm{CM}$ purified relaxin (2000-3000 U/mg) was used for iodination. Antiserum 1083 (1:18000 final dilution) or purified $\mathrm{PMAB}_{4}$ (1:750 final dilution) were used. The sensitivity of the assays was $20 \mathrm{pg} /$ tube and the interassay variation was $\leq 12 \%$ for readings between 80 and $300 \mathrm{pg}$. All values are given as $\mu$ g equivalents of NIH-RXN-PI pig relaxin standard.

\section{Results}

\section{Staining of corpora lutea}

In preliminary experiments for the immunohistochemical localization of relaxin a similar pattern of staining was obtained with all 3 antisera (PMAB PM $_{4}$ or 1083) on sections of CL from the luteal phase or early pregnancy. However, after absorption with $\mathrm{CM}$-a relaxin $(20 \mu \mathrm{g} / \mathrm{ml} \mathrm{diluted}$ antiserum), background staining was not completely abolished. In addition, the use of the PAP method did not produce intense staining on sections from non-pregnant animals. The specificity of the method was improved by purification of antiserum $\mathrm{PMAB}_{4}$ by affinity chromatography. The sensitivity was enhanced by application of the immunogold-silver technique.

Before Day 14, staining in CL from non-pregnant and pregnant animals was indistinguishable. No staining was seen in young CL (Day 3), which appeared as collapsed follicles with many infoldings. Between Day 5 (Fig. 1) and Day 7 (Fig. 2) relaxin staining was confined to theca cells around the edge and along the infoldings of the immature CL. In any one CL not all theca cells were stained. 


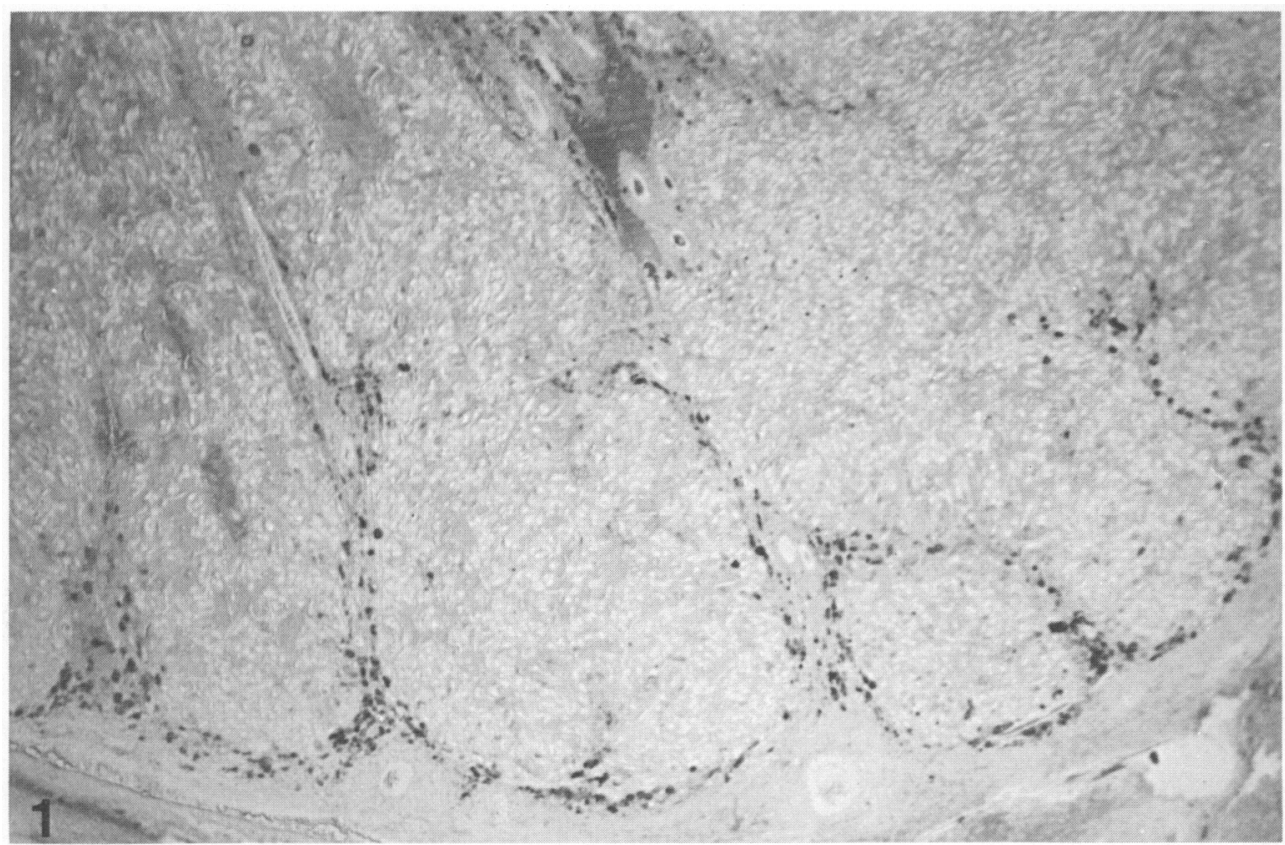

Fig. 1. Pig corpus luteum on Day 5 of the oestrous cycle stained for relaxin using unpurified $\mathrm{PMAB}_{4}$ anti-relaxin serum (1:750) and immunogold silver. Immunoreactive relaxin is localized to cells in the theca. $\times 40$.

By Day 9, staining on the very edge of the now solid, mature CL had decreased and relaxinimmunoreactive cells were dispersed (Fig. 3). At this time, the theca and granulosa layers would be expected to lose their distinctive boundary as the theca cells become disseminated amongst the large granulosa derived cells. A similar pattern was seen on Days 10, 11 and 12 .

By Day 14 of the oestrous cycle, an occasional ( $<1 \%$ of the total) stained, large cell was seen near the centre of the corpus luteum. At this stage, large luteal cells had vacuolated cytoplasm consistent with the beginning of luteolysis.

In contrast, on Day 14 of pregnancy many large cells were stained (Figs 4,5 ) and these cells showed no signs of vacuolated cytoplasm. Some densely stained cells were found amongst the majority of faintly stained ones. The intensity of staining had increased considerably by Day $2 \theta$ of pregnancy; the majority of large cells were densely stained, but no staining was seen in small cells (Fig. 6). The staining was most intense in the last sample examined (Day 31 of pregnancy).

A corpus albicans on Day 22 of the cycle, characterized by luteolytic regression and invasion of connective tissue, showed no immunostaining.

Luteal tissue incubated with normal rabbit serum in place of primary antiserum showed no staining at all. When purified $\mathrm{PMAB}_{4}$ antiserum was pre-absorbed with $\mathrm{CM}$-a relaxin, staining was considerably reduced, but background staining was seen in connective tissue and in the central cavity especially when the immunogold-silver technique was used. No specific staining (Fig. 7) and a further reduction of background staining was found when purified $\mathrm{PMAB}_{4}$ antiserum was depleted of antibodies using solid-phase relaxin, i.e. CM-a relaxin coupled to Sepharose beads.

The staining pattern for alkaline phosphatase was initially associated with the theca interna of follicles. After ovulation it was found in small cells which were dispersed throughout the tissue by Day 20 of pregnancy (Fig. 8). Large luteal cells were not stained. In the pig, this enzyme is associated with the theca interna and endothelial cells whereas the granulosa is free of phosphatase activity throughout the cycle and early pregnancy (Corner, 1948). 


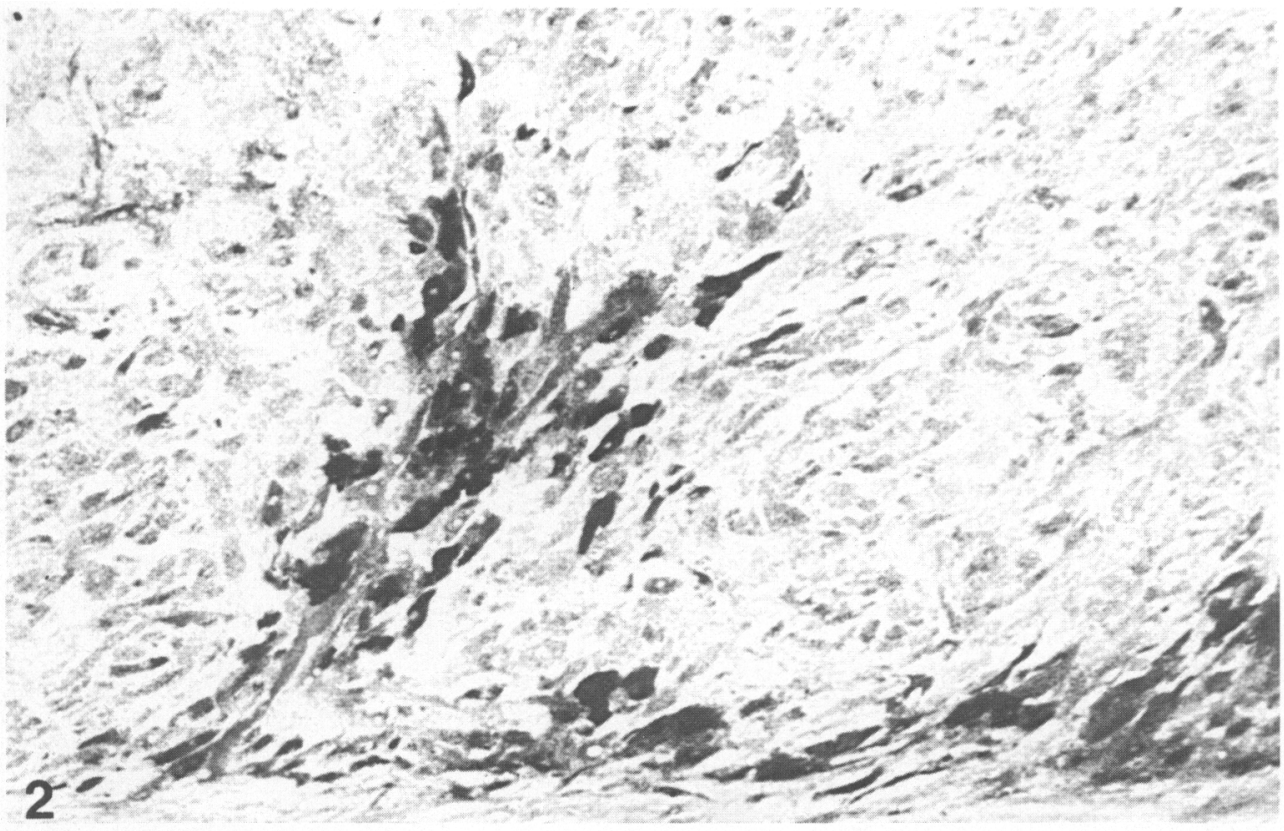

Fig. 2. Immunostaining of relaxin using purified $\mathrm{PMAB}_{4}$ anti-relaxin serum and immunogold silver on Day 7 of the oestrous cycle. The section is slightly overstained to show the morphology of the corpus luteum. $\times 160$.

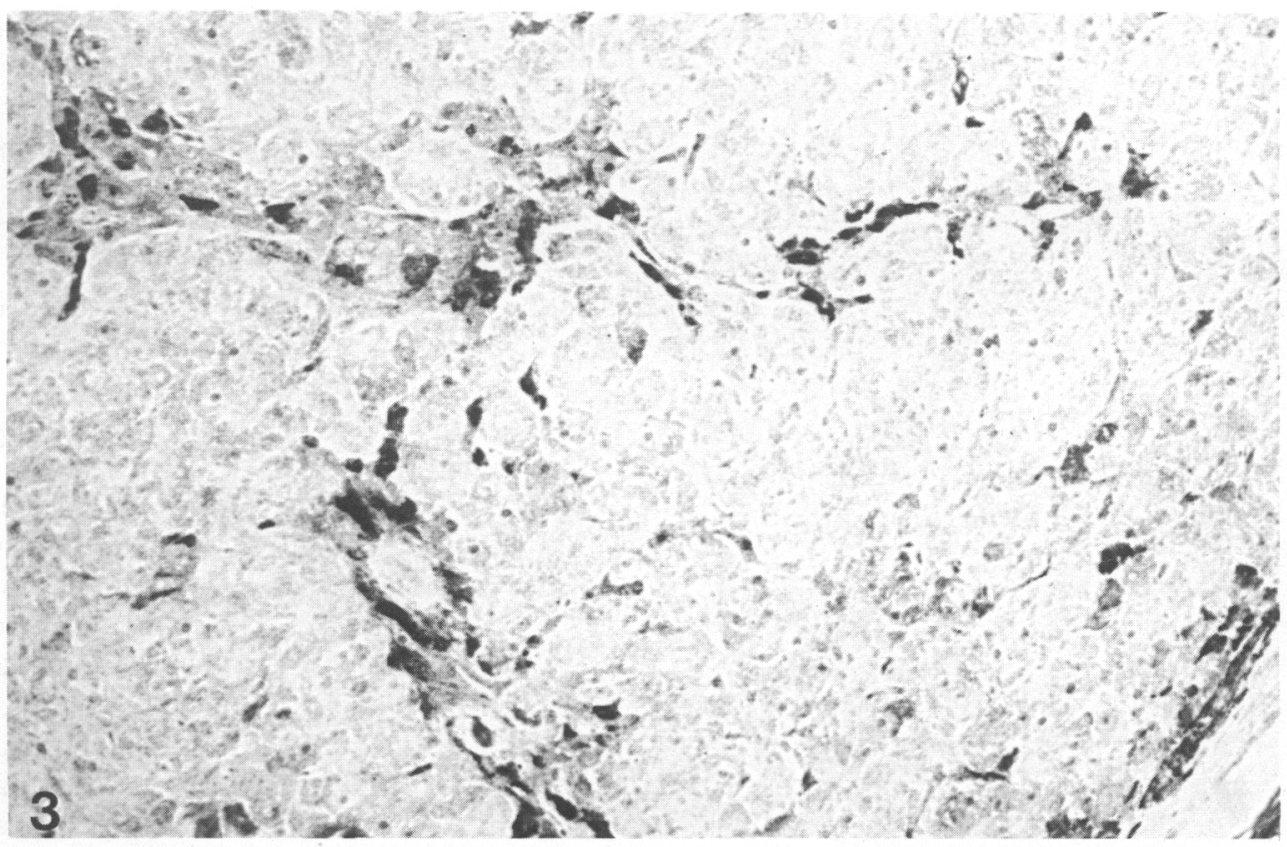

Fig. 3. Relaxin localization on Day 9 of the oestrous cycle using purified $\mathrm{PMAB}_{4}$ and immunogold silver. Dispersed clusters and individual relaxin immunoreactive cells were found. $\times 105$. 


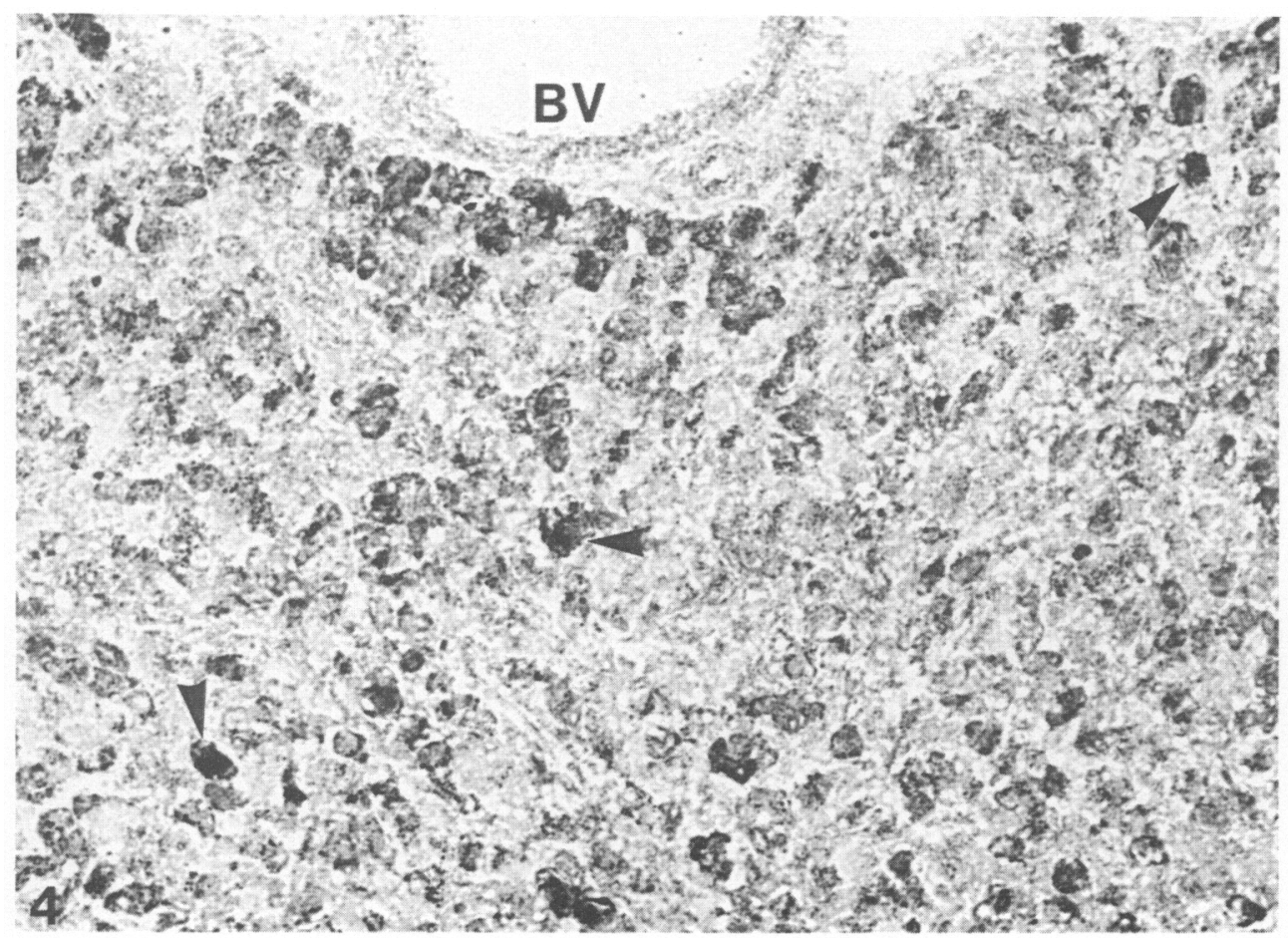

Fig. 4. Immunostaining of relaxin of a corpus luteum on Day 14 of pregnancy using purified $\mathrm{PMAB}_{4}$ antiserum and immunogold silver. Large luteal cells show different degrees of relaxinimmunoreactivity; a few very densely stained cells (arrows) are found among less densely stained cells. $\mathrm{BV}=$ blood vessel. $\times 135$.

Table 1. Relaxin concentrations $(\mu \mathrm{g} / \mathrm{g})$ in extracts of sow corpora lutea*

\begin{tabular}{|c|c|c|c|c|c|c|}
\hline \multirow[b]{2}{*}{ Day } & \multicolumn{3}{|c|}{ Antiserum 1083} & \multicolumn{3}{|c|}{ Antiserum $\mathrm{PMAB}_{4}$} \\
\hline & CL 1 & CL 2 & CL 3 & CL 1 & CL 2 & CL 3 \\
\hline \multicolumn{7}{|l|}{ Oestrous cycle } \\
\hline 3 & 0.02 & $0 \cdot 04$ & & 0.03 & 0.04 & \\
\hline 5 & $0 \cdot 04$ & $0 \cdot 04$ & 0.04 & $0 \cdot 03$ & $0 \cdot 04$ & 0.05 \\
\hline 8 & 0.09 & $0 \cdot 13$ & & $0 \cdot 07$ & $0 \cdot 11$ & \\
\hline 9 & 0.06 & 0.08 & & 0.07 & 0.07 & \\
\hline 10 & 0.08 & $0 \cdot 10$ & & 0.08 & 0.09 & \\
\hline 11 & 0.06 & 0.07 & & 0.07 & 0.07 & \\
\hline 12 & $0 \cdot 14$ & $0 \cdot 17$ & & $0 \cdot 15$ & $0 \cdot 16$ & \\
\hline 22 & 0.07 & 0.07 & & 0.07 & 0.08 & \\
\hline \multicolumn{7}{|l|}{ Pregnancy } \\
\hline 9 & 0.04 & 0.04 & 0.04 & 0.03 & 0.03 & 0.05 \\
\hline 11 & 0.07 & 0.08 & 0.08 & 0.07 & $0 \cdot 08$ & 0.08 \\
\hline 14 & $10 \cdot 0$ & $13 \cdot 3$ & & $9 \cdot 78$ & 11.65 & \\
\hline 20 & 640 & 646 & & 533 & 630 & \\
\hline 28 & 1270 & 1400 & & 1270 & 1480 & \\
\hline 31 & 1020 & 1655 & & 859 & 1970 & \\
\hline Pre-pubertal ovary & 0.003 & & & 0.009 & & \\
\hline
\end{tabular}

*Two or 3 corpora lutea were extracted for radioimmunoassay from each sow. They were assayed individually using 2 antisera (1083 or affinity purified $\mathrm{PMAB}_{4}$ ). 


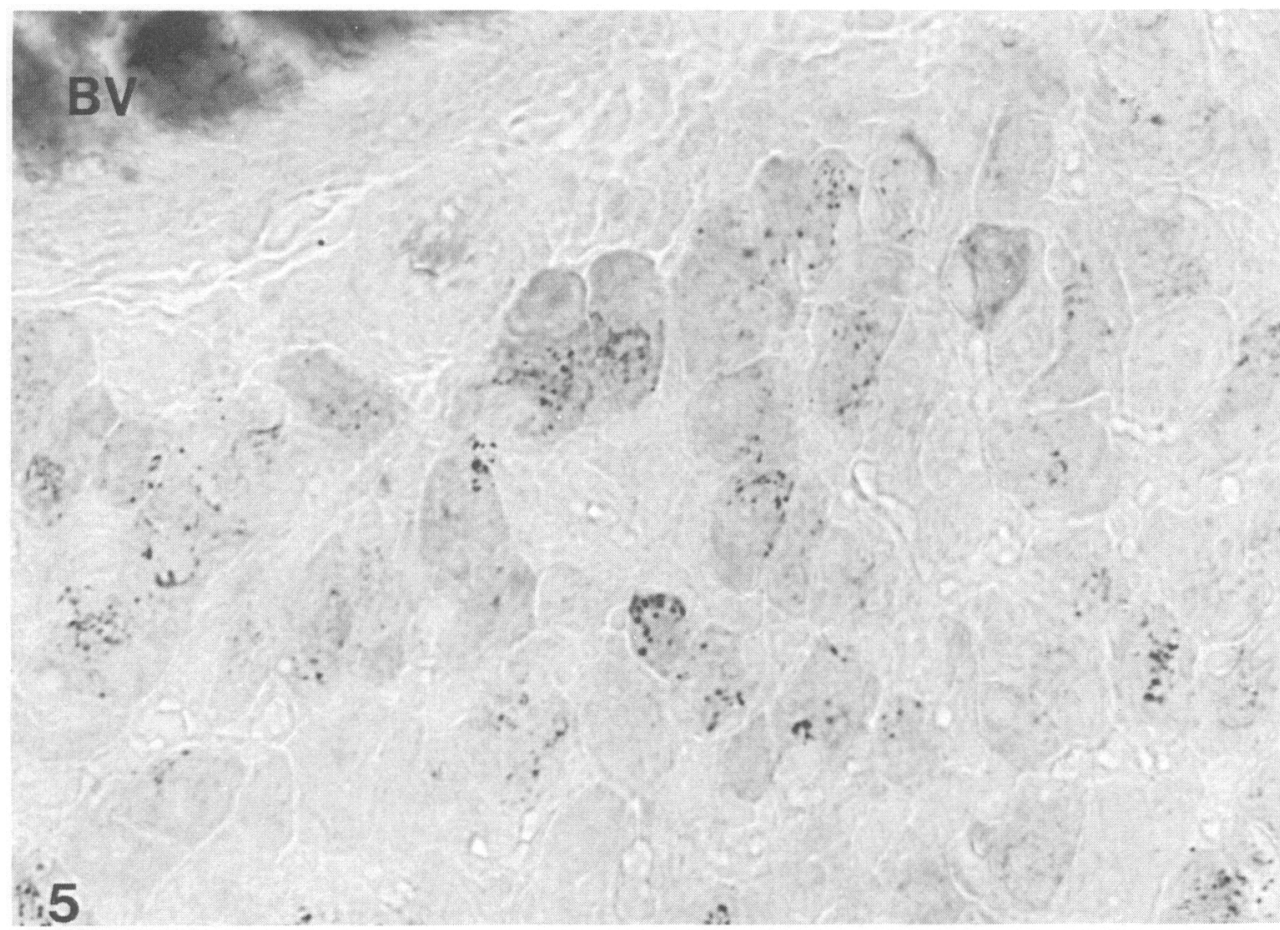

Fig. 5. Section of the same sample as in Fig. 4 stained by the peroxidase-anti-peroxidase method. In the cytoplasm of large luteal cells granular deposits mark the relaxin immunoreactive sites. Note the dark staining in the blood vessel (BV) caused by pseudo-peroxidase activity of erythrocytes. $\times 425$.

\section{Radioimmunoassay of CL extracts}

Determination of relaxin by radioimmunoassay using antiserum 1083 or purified $\mathrm{PMAB}_{4}$ showed that values were low throughout the oestrous cycle (see Table 1). Between Days 11 and 14 of pregnancy, however, there was a dramatic rise $(\sim 140$-fold $)$ in the content of relaxin immunoreactivity, which continued to rise as pregnancy progressed.

\section{Discussion}

No immunostaining was found on Day 3 of the luteal phase, in agreement with Ali et al. (1986). We found relaxin-immunoreactive theca-derived cells between Days 5 and 9 by immunohistochemistry, but this was not associated with a marked rise in the overall relaxin content of the CL, probably because of the small number of cells involved. Sherwood \& Rutherford (1981), however, using abattoir material did find high levels of relaxin in whole ovaries during the mid-luteal phase but histochemistry was not performed on these samples to check either the source of immunoreactivity or the ovarian histology. The physiological significance of relaxin for the young CL is unknown but it could be argued that as the theca in PMSG-stimulated gilts produces relaxin for a short period before ovulation (Evans et al., 1983; Bagnell et al., 1987) the immunostaining is due to relaxin stored in cells during the preovulatory period. However, immunostaining was reported to decline immediately before ovulation (Bagnell et al., 1987) and we found no staining until Day 5 after 


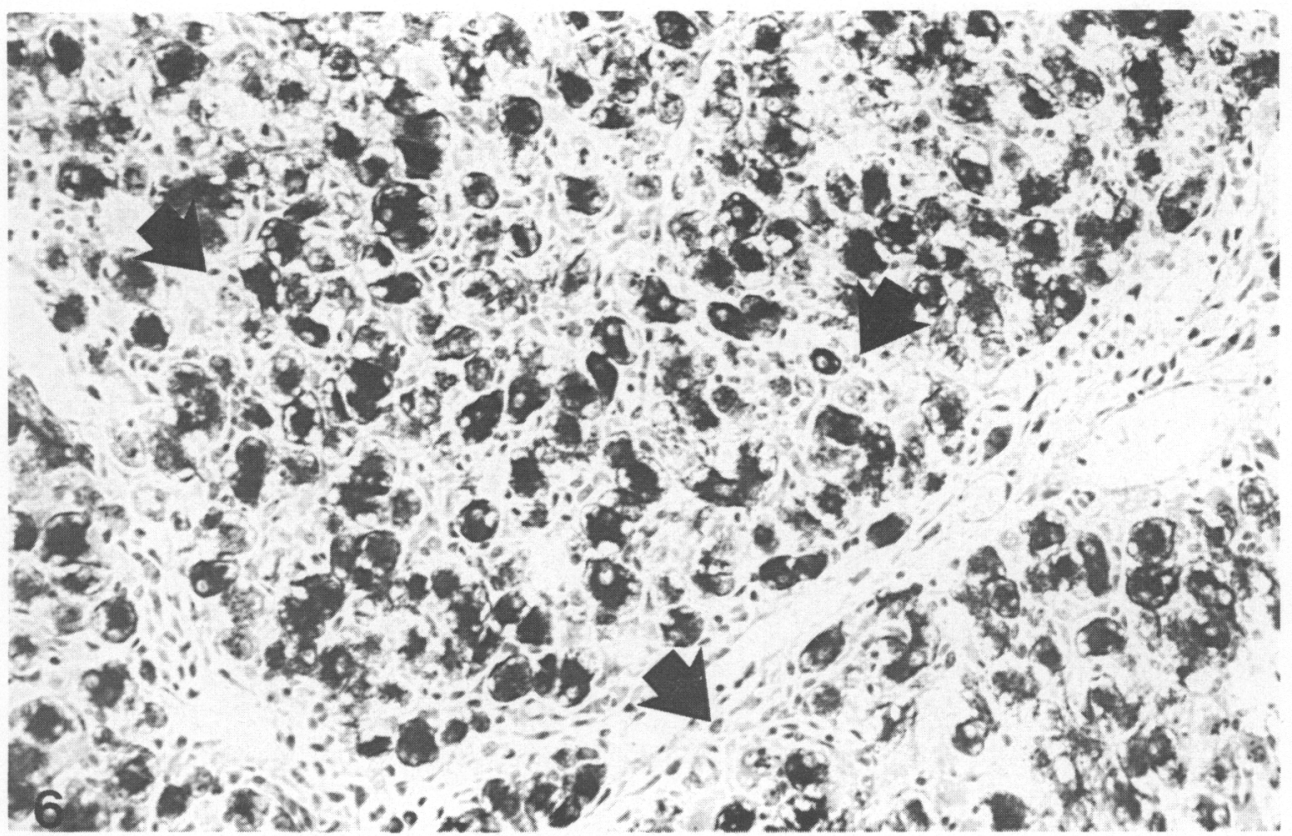

Fig. 6. A corpus luteum of pregnancy (Day 20) stained for relaxin using the immunogold-silver method and counterstained with haematoxylin. Relaxin immunoreactivity is localized to large luteal cells but not small cells (arrow heads). $\times 165$.

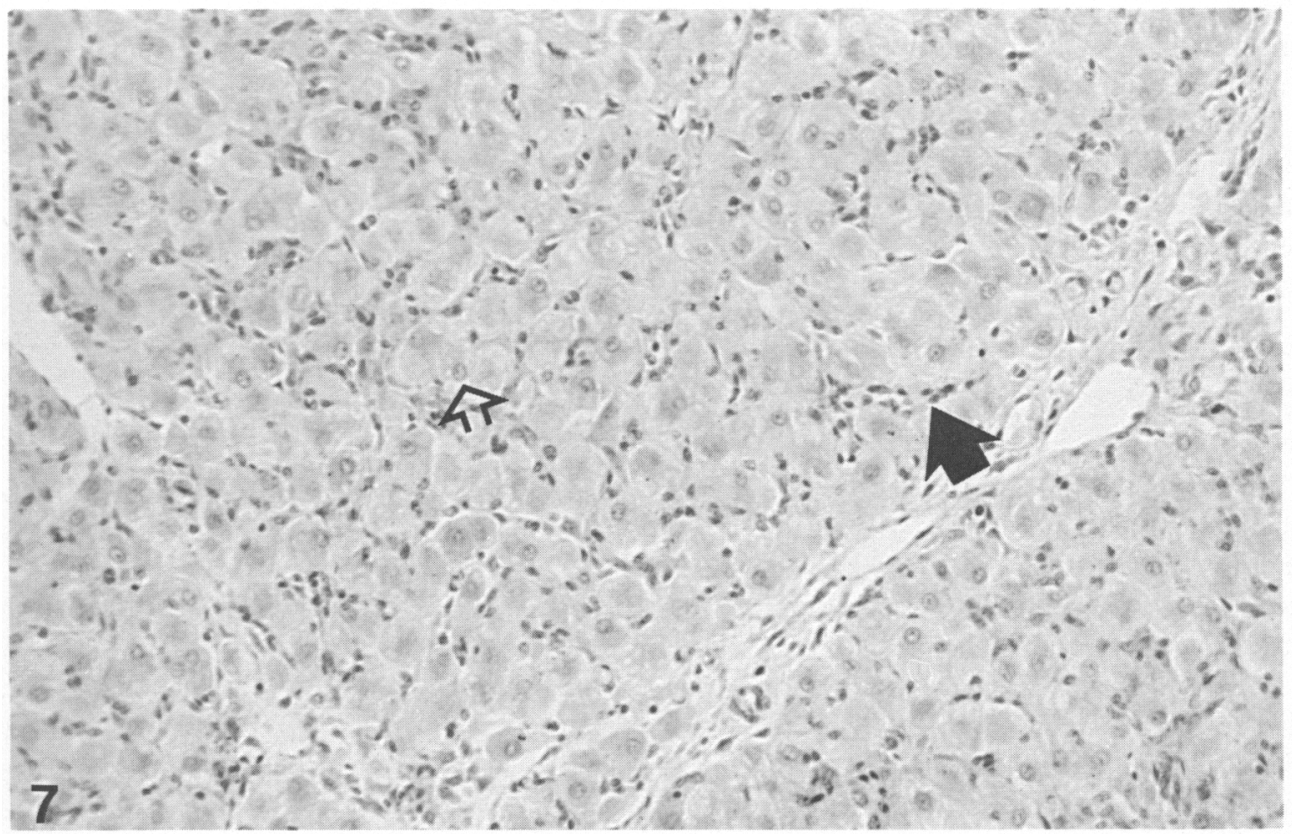

Fig. 7. A section of the same sample as in Fig. 6 incubated with purified anti-relaxin serum that was first absorbed with solid phase relaxin demonstrates the absence of immunostaining. The counterstaining with haematoxylin shows the difference between small cells $(\boldsymbol{\uparrow})$ and the large luteal cells $(\widehat{\text { A }) .} \times 165$. 


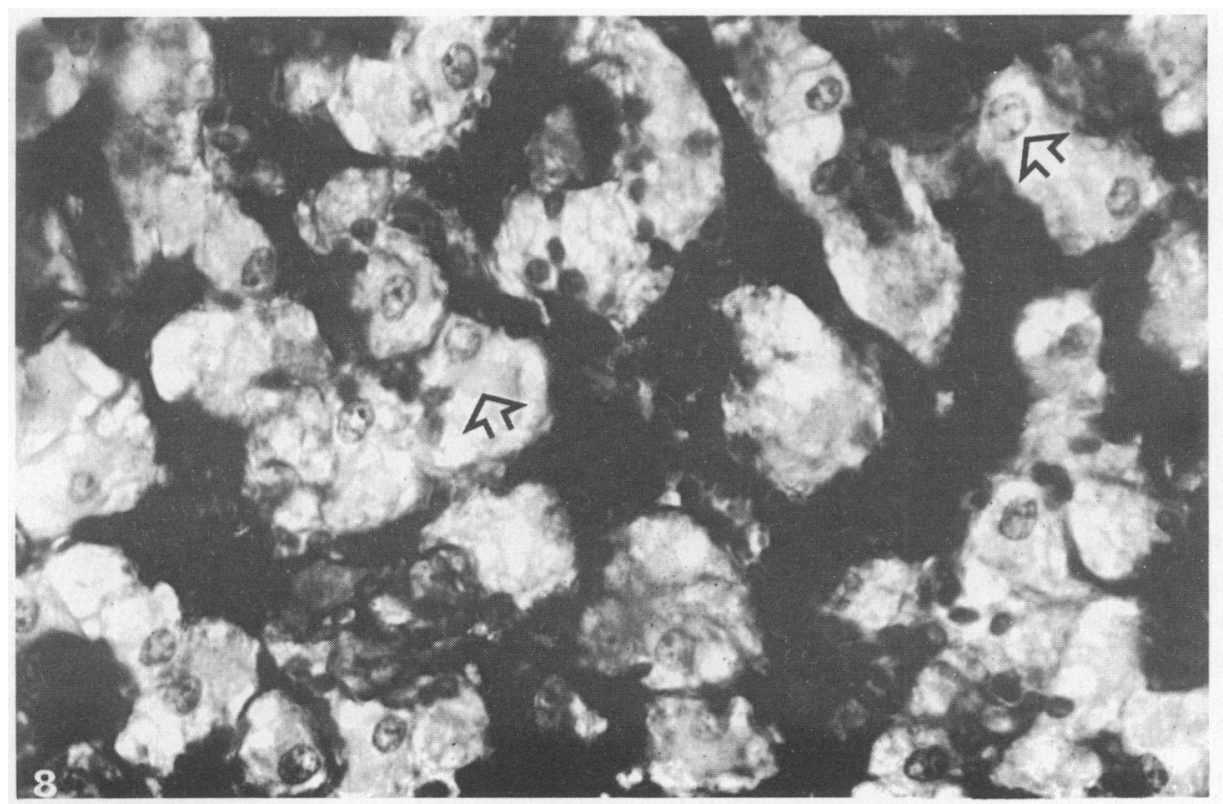

Fig. 8. Corpus luteum of early pregnancy stained for alkaline phosphatase activity counterstained with haematoxylin. Note that the large cells (arrows) do not stain. $\times 600$.

ovulation. The results are, therefore, compatible with the suggestion that the presence of immunoreactive relaxin is due to renewed synthesis by cells of thecal origin after ovulation.

Our results both by immunohistochemistry and radioimmunoassay demonstrate the presence of increasing concentrations of relaxin in large luteal cells in early pregnancy in the sow. This increased synthesis/storage of relaxin may begin as early as Days 12-14 after oestrus, at the time when the conceptuses begin significant oestradiol production (Heap et al., 1979). It is likely, however, that the CL does not need a signal from the conceptus to induce increased relaxin synthesis, but merely the prevention of luteolysis. This conclusion is based on the study of Anderson et al. (1973) who have shown that, if luteolysis is inhibited by hysterectomy in the early luteal phase, the relaxin content of corpora lutea obtained 40 days after oestrus is comparable to that in pregnant sows.

We found only a few stained large cells in sections from non-pregnant sows on Day 14 and this is probably due to luteolysis having begun, as the cells appeared very vacuolated compared to those in a $\mathrm{CL}$ from a Day-14 pregnant sow. This is consistent with the observation that progesterone concentrations begin to decline rapidly at this time in cyclic but not pregnant, pseudopregnant or hysterectomized animals (Parvizi et al., 1976; King \& Rajamahendran, 1988).

The staining patterns we obtained in CL from the luteal phase (Day 14) of non-pregnant sows and in samples from early pregnancy (Days 14 and 20) were very similar to those obtained by Fields \& Fields (1985), but differ from those of Ali et al. (1986) who found immunostaining in many cells throughout the luteal phase (Days 7-15) with greatest intensity on Days 11-15. There seems to be no obvious explanation for this discrepancy. It could be argued that whereas the antisera used by us and Fields \& Fields (1985) recognizes epitopes of relaxin itself, the antiserum used by Ali et al. (1986) might be able to detect a precursor form of relaxin present in granulosa-derived cells early in the luteal phase, although there is no direct evidence for this. Translatable relaxin mRNA has been 
isolated from CL of non-pregnant sows (Gast, 1982), but the time-course and/or site of its expression has not been studied.

Using alkaline phosphatase as a marker for theca-derived cells, we found that staining was present only in the theca interna and in all CL studied up to Day 20 of pregnancy only small cells stained. This is consistent with the work of Corner (1948). We were not able to immunostain identical samples because of different fixation protocols, but the similarity in staining pattern obtained using the two different techniques indicates that relaxin is initially present in theca-derived cells. In pregnancy, however, immunoreactive relaxin was found in large cells which were not associated with alkaline phosphatase and may be derived, therefore, from another cell type, probably granulosa cells.

Our histochemical data therefore suggest that by Day 14 a switch in relaxin synthesis from theca-derived cells to large luteal cells has occurred and that, in the absence of luteolysis, this is accompanied by a dramatic increase in the rate of synthesis. A switch in the site of synthesis would account for the observation that under certain conditions small amounts of relaxin are produced by pig granulosa cells which have been allowed to mature in culture (Loeken et al., 1983). The results by radioimmunoassay paralleled the staining pattern; low levels of immunoreactivity were detected when few cells were immunostained during the early luteal phase, with a dramatic rise in relaxin content on Day 14 of pregnancy which coincided with staining of increased intensity in nearly all large cells of the same sample. These parallel results confirm the presence or absence of relaxinimmunoreactivity in our samples.

This is the first evidence of which we are aware to suggest that the production site of a peptide hormone may switch from one type of cell to another in different physiological states.

We thank Dr Gordon King, Dr Morag Hunter and Dr George Foxcroft, for supplying corpora lutea; Dr O. D. Sherwood and Dr B. G. Steinetz for their kind gifts of antisera; Liz Wheatley for typing the manuscript; and the Medical Research Council for financial support.

\section{References}

Ali, S.M., McMurtry, J.P., Bagnell, C.A. \& BryantGreenwood, G.D. (1986) Immunocytochemical localization of relaxin in corpora lutea of sows throughout the oestrous cycle. J. Reprod. Fert. 34, 139-143.

Anderson, L.L., Ford, J.J., Melampy, R.M. \& Cox, D.F. (1973) Relaxin in porcine corpora lutea during pregnancy and after hysterectomy. Am. J. Physiol. 225, 1215-1219.

Bagnell, C.A., Frando, L.B., Downey, B.R., Tsang, B.K. \& Ainsworth, L. (1987) Localization of relaxin in the pig follicle during preovulatory development. Biol. Reprod. 37, 235-240.

Corner, G.W. (1919) On the origin of the corpus luteum of the sow from both granulosa and theca interna. Am. J. Anat. 26, 117-183.

Corner, G.W. (1948) Alkaline phosphatase in the ovarian follicle and in the corpus luteum. Contr. Embryol. Carn. Instn 32, 3-8.

Evans, G., Wathes, D.C., King, G.J., Armstrong, D.T. \& Porter, D.G. (1983) Changes in relaxin production by the theca during the preovulatory period of the pig. $J$. Reprod. Fert. 69, 677-683.

Fields, P.A. \& Fields, M.J. (1985) Ultrastructural localization of relaxin in the corpus luteum of the non-pregnant, pseudopregnant, and pregnant pig. Biol. Reprod. 32, 1169-1179.
Gast, M.J. (1982) Studies on luteal generation and processing of the high molecular weight relaxin precursor. Ann. N.Y. Acad. Sci. 380, 111-121.

Gomori, G. (1939) Microtechnical demonstration of phosphatase in tissue sections. Proc. Soc. exp. Biol. Med. 42, 23-26.

Heap, R.B., Flint, A.P. \& Gadsby, J.E. (1979) Role of embryonic signals in the establishment of pregnancy. Br. med. Bull. 35, 129-135.

King, G.J. \& Rajamahendran, R. (1988) Comparison of plasma progesterone profiles in cyclic, pregnant, pseudopregnant and hysterectomized pigs between 8 and 27 days after oestrus. J. Endocr. 119, $111-116$.

Larkin, L.H., Fields, P.A. \& Oliver, R.M. (1977) Production of antisera against electrophoretically separated relaxin and immunoffuorescent localization of relaxin in the porcine corpus luteum. Endocrinology 101, 679-685.

Loeken, M.R., Channing, C.P., D'Eletto, R. \& Weiss, G. (1983) Stimulatory effect of luteinizing hormone upon relaxin secretion by cultured porcine preovulatory granulosa cells. Endocrinology 112, 769-771.

O'Byrne, E.M. \& Steinetz, B.G. (1976) Radioimmunoassay (RIA) of relaxin in sera of various species using an antiserum to porcine relaxin. Proc. Soc. exp. Biol. Med. 152, 272-276. 
Parvizi, N., Elsaesser, F., Smidt, D. \& Ellendorff, F. (1976) Plasma luteinizing hormone and progesterone in the adult female pig during the oestrous cycle, late pregnancy and lactation, and after ovariectomy and pentobarbitone treatment. J. Endocr. 69, 193-203.

Sherwood, O.D. \& Rutherford, J.E. (1981) Relaxin immunoactivity levels in ovarian extracts obtained from rats during various reproductive states and from adult cycling pigs. Endocrinology 108, 1171-1177.

Sherwood, O.D., Rosentreter, K.R. \& Birkhimer, M.L. (1975) Development of a radioimmunoassay for porcine relaxin using ${ }^{125} \mathrm{I}$ labelled polytyrosol-relaxin. Endocrinology 96, 1106-1113.
Taverne, M., Bevers, M., Bradshaw, J.M.C., Dieleman, S.J., Willemse, A.H. \& Porter, D.G. (1982) Plasma concentrations of prolactin progesterone, relaxin and oestradiol-17 $\beta$ in sows treated with progesterone, bromocriptine or indomethacin during late pregnancy. J. Reprod. Fert. 65, 85-96.

Walsh, J.R. \& Niall, H.D. (1980) Use of an octadecylsilica purification method minimizes proteolysis during isolation of porcine and rat relaxins. Endocrinology $107,1258-1260$.

Received 10 June 1988 